\title{
EFFICACY OF PROTEIN MIX SUPPLEMENTATION AMONG MALNOURISHED CHILDREN IN SELECTED PRESCHOOLS OF BENGALURU RURAL AREA, KARNATAKA STATE, INDIA
}

\author{
Jayalakshmi N1, Pity Koul2 ${ }^{2}$ S. Kamalam ${ }^{3}$ \\ 1 Professor, Department of Nursing, Government College of Nursing, Bengaluru, Karnataka, India. \\ 2 Professor and Co-ordinator for Nursing Research, IGNOV, New Delhi, India. \\ ${ }^{3}$ Dean of Nursing, Sri Balaji Vidyapeeta, Gandhi Medical College, Puducherry, Tamilnadu, India.
}

\begin{abstract}
\section{BACKGROUND}

Today's children are the future of the nation. Nutrition adequacy is one of the key determinants of the health and well-being of the children. Malnutrition is a major public health problem in the world today, particularly in preschool children, who are more vulnerable to the effects of malnutrition. Every alternate child suffers from malnutrition in India and every third malnourished child in the world is an Indian. A planned intervention is effective in increasing the nutritional status of preschool children in the prevention of protein energy malnutrition.

The study aimed to evaluate the efficacy of the protein mix supplementation on the nutritional status of the malnourished children and to determine the association between the post-interventional nutritional status of the children and their selected baseline variables.
\end{abstract}

\section{MATERIALS AND METHODS}

A randomised controlled trial was used for the study. A total of 544 preschool children from four schools were screened for the presence of malnourishment using the Indian Academy of Paediatrics (IAP) classification. The sample size was determined by power analysis. A structured interview schedule was used to collect the baseline data. Physical assessment of children was undertaken to know their nutritional status using the ICMR modified rating scale. Protein mix nutritious balls (Bengaluru Poushtika Thambittu) served six days per week for three months and health dairy was maintained throughout the study.

\section{RESULTS}

The study revealed that the nutritional status of the preschool children in the experimental group was significantly higher than in the control group at 0.05 level after intervention of Bengaluru Poushtika Thambittu (BPT). The mean score increased from 14.02 to $16.27,98.95$ to 101.11 and 14.38 to 15.36 were weight, height and mid upper arm circumference respectively in the experimental group as compared to the control group. The post-test mean difference scores of physical assessment were higher in the experimental group (17.0) as compared to the control group (1.9) ( $\mathrm{t}$-value $=34.4$, $\mathrm{p}$-value $=0.00$ ).

\section{CONCLUSION}

The study findings clearly indicate that Bengaluru Poushtika Thambittu was effective in increasing the nutritional status of the preschool children in the prevention of protein energy malnutrition.

\section{KEY WORDS}

Protein Energy Malnutrition, Malnourished Children, Bengaluru Poushtika Thambittu (BPT), Anthropometric Measurements, Physical Assessment.

HOW TO CITE THIS ARTICLE: Jayalakshmi N, Koul P, Kamalam S. Efficacy of protein mix supplementation among malnourished children in selected preschools of Bengaluru rural area, Karnataka State, India. J. Evolution Med. Dent. Sci. 2018;7(33):3693-3698, DOI: $10.14260 /$ jemds/2018/829

\section{BACKGROUND}

Malnutrition is a major public health problem worldwide today, particularly in children under five years of age. Protein Energy Malnutrition (PEM) is the most widely prevalent form of malnutrition in developing and underdeveloped nations. The nutritional status of children is an indication of the nutritional profile of the entire community. ${ }^{1}$ Preschool is a vulnerable period for the child, especially from the growth and development standpoint.

'Financial or Other Competing Interest': None.

Submission 02-07-2018, Peer Review 27-07-2018,

Acceptance 02-08-2018, Published 13-08-2018.

Corresponding Author:

Dr. Jayalakshmi $N$,

Professor,

Government College of Nursing,

Bengaluru-560002, Karnataka, India.

E-mail: jlakshmiraju2000@gmail.com

DOI: $10.14260 /$ jemds $/ 2018 / 829$

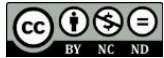

The physical activity increases considerably and needs a higher intake of nutrients, particularly protein and energygiving foods, to prevent protein energy malnutrition like kwashiorkor and marasmus. ${ }^{2}$

Undernutrition has been identified as a major public health problem in India. Majority of the children suffering from mild-to-moderate forms of malnutrition remain hidden within the community. Malnutrition is mainly caused by poverty and lack of food, poor environmental condition, large family size, poor maternal health, failure of lactation, premature termination of breast feeding and adverse cultural practices. The incidence of protein energy malnutrition is more in preschool children. This problem exists in all the states and nutritional marasmus is more frequent than kwashiorkor. ${ }^{3}$

The various symptoms mainly include pale, thick and dry skin which may bruise easily, changes like thin, tightly curled hair and pulled out easily; visual disturbances include night blindness and increased sensitivity to light and glare. Other 
symptoms include anaemia, diarrhoea, disorientation, irritability, anxiety, attention deficit, loss of reflexes, lack of muscular coordination, muscle twitches and scaling and cracking of the lips of the mouth. ${ }^{4}$

Protein energy malnutrition is by far the most lethal form of malnutrition. Children are its most visible victims. Malnutrition, "the silent emergency" is an accomplice in at least half of the 10.4 million child deaths each year in the developing world. Protein energy malnutrition affects every fourth child worldwide. Geographically, more than $70 \%$ of PEM children live in Asia, $26 \%$ in Africa and $4 \%$ in Latin America and Caribbean. ${ }^{5}$

The report of a survey regarding Hunger and Malnutrition called HUNGAMA conducted by the NANDI group was released by the ex-Prime Minister of India on 10th Jan 2012. The results showed that the level of undernutrition in India is unacceptably high, that is $42 \%$ of the children are underweight and $59 \%$ of the children under the age of five are stunted. The ex-prime minister stated that every third malnourished child in the world is an Indian. ${ }^{6}$

Malnutrition among children under the age of five is an important concern for the health authorities in India. The aim of the present review was to assess the burden of undernutrition. Existing (2015) evidence shows that the prevalence of undernutrition among children was high and varied widely $39-75 \%, 15.4-74 \%$ and $10.6-42.3 \%$ were underweight, stunting and wasting, respectively. ${ }^{7}$

According to the District Level Household and Survey (DLHS) in Karnataka (2012 - 13), the percentage of malnutrition in urban and rural for children under the age of five was $29.8 \%$ and $29.6 \%$, respectively. ${ }^{8}$ The ICDS and NRHM programmes have been running effectively in India. Many researches show that severe malnourished children have been reduced, but even now the grade I and II malnourished cases have not decreased. Though overnutrition is not a major problem in India, negligence towards it may cause a greater problem in the future.

In 1978, the World Health Assembly decided that the main social target of the government and WHO in the coming decades should be to attain health for all citizens by the year 2000 AD. ${ }^{9}$ According to the Declaration of Alma-Ata, it has not achieved the expected goals so far.

Hence, the researcher has evinced keen interest to identify the malnutrition rate in preschool children and has planned to provide protein mix supplementation for three months to evaluate the efficacy of the protein mix supplementation among children in the selected preschools of Bengaluru rural area, Karnataka state, and in-turn reduce the mortality and morbidity of these dreadful diseases.

\section{Objectives}

1. To assess the nutritional status of children in the selected preschools of Bengaluru rural area.

2. To evaluate the efficacy of the protein mix supplementation on the nutritional status of the malnourished children in the experimental group.

3. To determine the association between the postinterventional nutritional status of the children and their selected baseline variables.

\section{MATERIALS AND METHODS}

A randomised controlled trial was used for the study. The population included the preschool children of Madanayakanahalli, which comes under the Makali Primary Health Centre, rural area of Bengaluru, Karnataka state. The sample size was determined by power analysis. Multistage cluster sampling technique was used in this study. A total of 544 preschool children were assessed from four schools to find their nutritional status such as weight, height and midarm circumference, which was graded according to the Indian Academy of Paediatrics classification. Among the 544 children, 256 were undernourished. About 146 children were grade I, 58 children were grade II malnourished, 52 children were grade III malnourished and none were grade IV malnourished. As per the inclusion criteria, 204 children with grade I and grade II malnourishment were selected as subjects for the study. Grade III malnourished children were referred to the Makali Primary Health Centre for further management. Total enumeration sampling technique was employed and the samples were randomly assigned using the lottery method to the experimental group (102) and the control group (102). A structured interview schedule was used to collect the baseline data. Physical assessment of children was undertaken to know their nutritional status using the ICMR modified rating scale. Physical assessment (head-to-toe) to know the nutritional status as per the ICMR modified rating scale, before and after the intervention was used. The rating scale contains 1, 2, 3, 4 scores for a total 24 statements in the form of multiple options of four. The total score was 96.

A pilot study was conducted and study was found to be feasible. Prior to data collection, ethical permission was obtained from the Institutional Ethical Committee and formal permission was obtained from school authority. Consent was taken from parents of children. Before the intervention, all the subjects belonging to the experimental and the control group were dewormed with tablet Albendazole $400 \mathrm{mg}$. Protein mix nutritious balls (Bengaluru Poushtika Thambittu) of 308 kilocalories weighing 75 gm each were prepared as per the ICMR recommendation by the investigator at home with each ball containing 12 grams of protein per 75 grams. This was served six days per week for three months to the experimental group. Anthropometric measurements such as weight, height and mid-arm circumference were taken every month as post-test 1 , post-test 2 and post-test 3 . Physical assessment was taken before and after intervention for both the groups. Health dairy was maintained throughout the study.

\begin{tabular}{|c|c|c|c|c|}
\hline $\begin{array}{c}\text { Sl. } \\
\text { No. }\end{array}$ & Ingredients & Amount & Protein & Calories \\
\hline 1 & Roasted soya bean & $10 \mathrm{gms}$ & $4.32 \mathrm{gms}$ & 43 \\
\hline 2 & Roasted bengal gram & $10 \mathrm{gms}$ & $2.25 \mathrm{gms}$ & 34 \\
\hline 3 & Roasted groundnut & $15 \mathrm{gms}$ & $3.93 \mathrm{gms}$ & 85 \\
\hline 4 & Roasted ragi & $20 \mathrm{gms}$ & $1.46 \mathrm{gms}$ & 66 \\
\hline 5 & Jaggery & $20 \mathrm{gms}$ & $0.08 \mathrm{gms}$ & 77 \\
\hline \multicolumn{4}{|c|}{ Table 1. Ingredients and Calories in the Bengaluru } \\
Poushtika Thambittu & $\mathbf{3 0 7 . 8}$ \\
\hline
\end{tabular}


The Data Collection Procedure was conducted in Four Phases-

1. Phase-1: Assess for nutritional status among preschool children.

2. Phase-2: Pre-test for control and experimental group.

3. Phase-3: Preparation and administration of Bengaluru Poushtika Thambittu (BPT) to the undernourished preschool children of the experimental group and keeping the control group under observation.

4. Phase-4: Post-test for both control and experimental group.

\section{Statistical Analysis}

The data obtained was analysed in terms of the objectives of the study using descriptive and inferential statistics. Frequency, percentage, mean and standard deviation were used to classify the baseline data. Chi-square test was used to assess the homogeneity of sample between the groups and association with variables. Student's ' $\mathrm{t}$ ' test was used to compare the variables before and after the intervention within the group. Paired ' $\mathrm{t}$ ' test was used to assess the efficacy of the protein mix supplementation between the control group and the experimental group. The data was analysed using the Statistical Package for Social Sciences (SPSS version 19).

\section{RESULTS}

1. To assess the nutritional status of children in the selected preschools of Bengaluru rural area.

A total of 544 preschool children were assessed from four schools to find out the nutritional status of children by using Indian Academy of Paediatrics classification. 270 (49.63\%) children were normal nutritional status, 256 (47.05\%) were undernourished and $18(03.32 \%)$ were overnourished. 146 (26.83\%), 58 (10.66\%) and 52 (9.55\%) children were Gr I, Gr II and Gr III malnourished respectively and none of them had Gr IV malnutrition.

2. To evaluate the efficacy of the protein mix supplementation on the nutritional status of the malnourished children in the experimental group.

The study revealed that the nutritional status of the preschool children in the experimental group was significantly higher than in the control group at 0.05 level after intervention of Bengaluru Poushtika Thambittu (BPT). The mean score increased from 14.02 to $16.27,98.95$ to 101.11 and 14.38 to 15.36 were weight, height and midupper arm circumference respectively in the experimental group as compared to the control group.

\begin{tabular}{|c|c|c|c|c|c|c|}
\hline & & Mean & SD & Mean Difference & T-value & P-value \\
\hline \multirow{2}{*}{ Pre-test Score } & Control & 62.25 & 3.117 & \multirow{2}{*}{3.3725} & \multirow{2}{*}{4.928} & \multirow{2}{*}{$\begin{array}{l}.054 \\
\text { (NS) }\end{array}$} \\
\hline & Experimental & 65.63 & 6.169 & & & \\
\hline \multirow{2}{*}{ Post-test score } & Control & 66.07 & 3.533 & \multirow{2}{*}{16.529} & \multirow{2}{*}{25.307} & \multirow{2}{*}{$.000^{* *}$} \\
\hline & Experimental & 82.60 & 5.571 & & & \\
\hline
\end{tabular}

Table 2. The Mean Physical Assessment of pre-test and post-test score within the Control and the Experimental Group

${ }^{* *}=$ Significant at $\mathrm{p}<0.01$ level, ${ }^{*}=$ Significant at $\mathrm{p}<0.05$ level, NS $=$ Significant at $\mathrm{p}>0.05$ level.

From above Table 2 depicts that the pre-test nutritional score among the control and experimental group is found to be statistically non-significant as p-value is greater than 0.05 $(\mathrm{t}=4.928, \mathrm{p}=0.054)$ and clearly shows mean difference in pre-test score of 3.37. The mean of pre-test score for control and experimental group is 62.25 and 65.63 respectively. The results concluded that there is no significant difference between control and experimental group.
The post-test nutritional score between the control and experimental group is found to be statistically significant, as $\mathrm{p}$-value is less than $0.05(\mathrm{t}=25.307, \mathrm{p}=0.000)$. The mean of the post-test score for control and experimental group is 66.07 and 82.60 respectively. Above results indicates that there is significant difference in nutritional score between the groups and can conclude that there is massive increase in nutritional status of children after introducing to protein mix to the children of experimental group.

\begin{tabular}{|c|c|c|c|c|c|c|c|c|c|c|}
\hline \multirow[t]{2}{*}{ Test } & \multicolumn{5}{|c|}{$\begin{array}{l}\text { Control Group } \\
n=102\end{array}$} & \multicolumn{5}{|c|}{$\begin{array}{c}\text { Experimental Group } \\
n=102\end{array}$} \\
\hline & Mean & SD & MD & t-value & p-value & Mean & SD & MD & t-value & p-value \\
\hline Pre-test Score & 62.3 & 3.1 & \multirow{2}{*}{1.9} & \multirow{2}{*}{0.2} & \multirow{2}{*}{$0.1^{\mathrm{NS}}$} & 65.6 & 6.2 & \multirow{2}{*}{17.0} & \multirow{2}{*}{34.4} & \multirow{2}{*}{$0.00^{* *}$} \\
\hline Post-test Score & 66.1 & 3.5 & & & & 82.6 & 5.6 & & & \\
\hline & Tal & 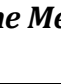 & 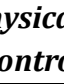 & essme & $\begin{array}{l}\text { pre-te } \\
\text { imento }\end{array}$ & $\begin{array}{l}\text { post- } \\
\text { p }\end{array}$ & core & & & \\
\hline
\end{tabular}

${ }^{* *}=$ Significant at $\mathrm{p}<0.01$ level, ${ }^{*}=$ Significant at $\mathrm{p}<=0.05$ level, NS (Non-Significant) $=\mathrm{p}>0.05$

From the above Table 3 depicts that the mean physical assessment of pre-test and post-test score in the control and the experimental group. This clearly indicates that the mean difference of the post-test scores of the experimental group was high (17.0) when compared to the control group (1.9) $(\mathrm{t}$-value $=34.4, \mathrm{p}$-value $=0.00)$. So it has been proved that there is improvement in the nutritional status of the children. Hence, it is statistically significant at 0.05 level. The above findings are depicted in Fig. 1 . 


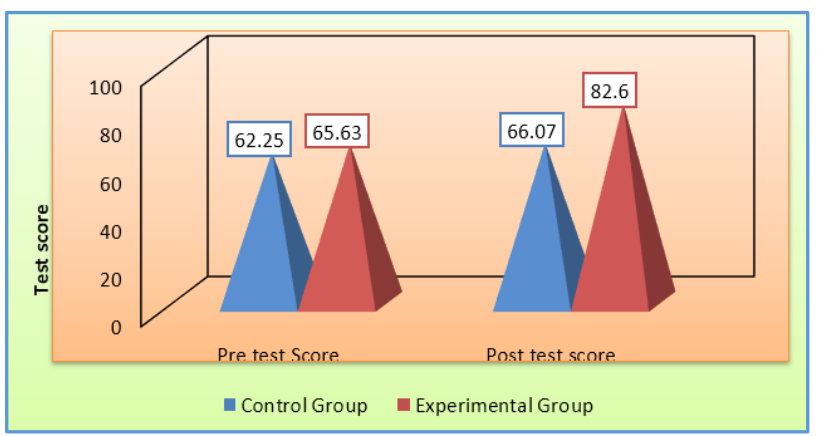

Figure 1. The Mean Physical Assessment of pre-test and post-test score in the Control and the Experimental Group

3. To determine the association between the postinterventional nutritional status of the children and their selected baseline variables.

The study revealed that the association between the postinterventional nutritional status of children and the educational status of mother $(p=0.86)$, educational status of father $(p=0.09)$, occupational status of mother $(p=0.054)$, occupational status of father $(\mathrm{p}=0.25)$, type of the family $(p=0.29)$, monthly income of the family $(p=0.72)$, food pattern $(p=0.47)$, source of information $(p=0.28)$, age of the child $(p=0.45)$, gender of the child $(p=0.23)$, last dose of deworming medication received by child $(p=0.48)$, exclusive breast feeding $(p=0.99)$ and duration of breast feeding $(p=0.71)$ were found to be non-significant.

\section{DISCUSSION}

A total of 544 preschool children from four schools were assessed and the results revealed that almost half the subjects $(47.05 \%)$ were undernourished. These findings were similar to other studies and revealed that $44.5 \%$ in Volta region of Ghana, $40.8 \%$ in Rajasthan, $43.67 \%$ in Gujarat, $47.30 \%$ in Sri Lanka, $48.30 \%$ in West Bengal, $41.2 \%$ in Uttar Pradesh, 35\% in Japan and $47.10 \%$ in Karnataka.

The mean of physical assessment in the control and the experimental group clearly indicates that the mean difference of the post-test scores of the experimental group was high (17.0) when compared to the control group (1.9) (t-value $=34.4$, p-value $=0.00)$. So, it has been proved that there was improvement in the nutritional status of the children. These findings were justified by the study conducted to estimate the effect of supplementary feeding on the prevention of wasting in preschool children at a rural area. The study revealed that the energy intake in the supplemented group was higher than in the non-supplemented group by $16-18 \%$ of the recommended daily intake. The corresponding difference in protein intake was $45-80 \%$ of the recommended daily intake. ${ }^{10}$

These findings are similar in another study conducted on nutritional intervention on malnutrition in $3-6$ years old rural children. The results were analysed using paired t-test by SPSS V.16 software. The prevalence of wasting (mild and moderate) and severe malnutrition after intervention reduced from 14.2 and 0.95 to 12.6 and $0.5 \%$, respectively ( $\mathrm{p}<0.05$ ). Receiving a cooked meal significantly decreased wasting (15.2 - 13.2\%) in all the children ( $\mathrm{p}<0.05)$. Nutritional intervention with cooked meal for 175 days had significant reduction in wasting in all the children. ${ }^{11}$
The study revealed that the association between the postinterventional nutritional status of children and the educational status of mother $(\mathrm{p}=0.86)$, educational status of father $(p=0.09)$, occupational status of mother $(p=0.054)$, occupational status of father $(p=0.25)$, type of the family $(p=0.29)$, monthly income of the family $(p=0.72)$, food pattern $(p=0.47)$, source of information $(p=0.28)$, age of the child $(p=0.45)$, gender of the child $(p=0.23)$, last dose of deworming medication received by child $(p=0.48)$, exclusive breast feeding $(p=0.99)$ and duration of breast feeding $(p=$ 0.71 ) were found to be non-significant.

The similar study findings supported that the nonsignificant impact of the Hyderabad mix on the experimental group with their type of family $\left(0.16^{\mathrm{NS}}\right)$, family income $\left(0.36^{\mathrm{NS}}\right)$, number of siblings $\left(2.05^{\mathrm{NS}}\right)$, ordinal position $\left(1.37^{\mathrm{NS}}\right)$ and number of children $\left(1.88^{\mathrm{NS}}\right)$ at 0.05 level.12 $\mathrm{A}$ case control study was conducted on risk factors for under-nutrition among children aged one to five years in Udupi taluk of Karnataka, India. The results showed that lack of exclusive breast feeding and level of education of the caregiver did not have an association. ${ }^{13}$

\section{Nursing Implications}

The findings of the study have implications in the field of nursing education, nursing practice, nursing research and nursing administration.

\section{Nursing Education}

- The results of the study emphasise the need to include more content in the current nursing curriculum on malnutrition and its management.

- Be trained during their pre-service and in-service by the nurses to educate parents/ caretaker of preschool children regarding malnutrition.

- Emphasis should be on health education and training programmes among nurse educators, to update knowledge and attitude regarding mothers of preschool children in managing malnourished children by using protein rich foods.

\section{Nursing Practice}

- The nurse practitioner, school health nurse, health educators, family health nurse and ASHA workers play a vital role in imparting health services at all levels of participation, promotion and treatment of malnutrition.

- Health promotion is a key part of all health services, whenever they are provided. Through education, nurses will be able to develop the skill necessary to use every opportunity to promote health in every practice. This will necessitate inclusion of multidisciplinary teams and an evaluator from the perspective of the malnourished children.

- Discussion between nursing students and qualified staff could be one way to develop knowledge regarding management of malnourished children.

- In-service education programmes can be arranged for the nurses regarding protein mix administration for children, as it would be the most effective method for enhancing their nutritional level. 
- $\quad$ School health nurses can actively participate in school health programmes by providing the protein mix and indirectly help in achieve the goals of the health services.

- The family health nurse, ASHA workers and the community health nurse can conduct nutrition programmes at the PHC to improve the nutritional level of the malnourished children.

\section{Nursing Administration}

- A nurse administrator can arrange in-service education, continuing education and special training programmes for junior health assistants, health workers, ASHA workers, school health nurses and teachers regarding the administration of protein rich food for children on a regular basis in the health centres.

- Having round table discussion on problems of malnutrition with complications, how it occurs and the social and economic burden on the family due to this.

- More specifically nurses should be involved in the development of policies for education, intervention and legislative changes to reduce the adverse effects of health transition.

- The health administrator should implement new plans, policies and approaches regarding the preparation and administration of protein rich foods to manage malnutrition in preschool children.

- Nurses should be aware and active in National and International agencies involved in global social, health, nutrition and welfare such as the WHO, UNICEF, UNDP, and the World Bank.

\section{Nursing Research}

- There is an urgent need to go in-depth on malnutrition by conducting more evidence-based research in hospitals as well as in communities to evaluate the comorbidity associated with malnutrition.

- Extensive research must be conducted to identify more effective protein rich foods like soya, Bengal gram, etc. for preschool children.

- More research can be done regarding the prevention of malnutrition to reduce morbidity and mortality.

- More studies are needed in different settings and aspects like causes and prevention of malnutrition among preschool children of different samples.

\section{Limitations}

- The investigator could not have any control over the home supplements received by the preschool children.

- The investigator could not have any control over the absence of preschool children.

\section{Recommendations}

- Mass information and awareness programmes are needed to alert the government and communities on the importance of health and nutritional requirements of the preschool children.

- Protein energy malnutrition prophylaxis programme must concentrate more on bio-available protein. The medication of protein should have effective monitoring.
- Educational campaign is essential for the mothers of preschool children with regard to the menu, maintaining community kitchen garden, macro and micronutrient interactions and absorption-promotion foods in the diet.

- Intervention in the form of supplementary feeding would help in prevention or at least delay the complications, and thus reduce the burden due to malnutrition in India.

- Community-based approaches need to be developed for sustained strengthening of household food security with emphasis on nutritional adequacy for preschool children.

- An evaluative survey can be taken to investigate the availability of health and nutrition education facilities in government schools.

- Manuals and information booklets can be developed to enhance the nutritional level of malnourished preschool children.

- There is need to conduct similar studies in other taluks of Bengaluru such as south, east and Anekal taluk, so that comparative statistics can be obtained on the prevalence of malnutrition and policies can be formed accordingly.

\section{CONCLUSION}

'Protein Energy Malnutrition' is one of the 'silent emergencies' seen in preschool children and more in rural communities and such children are found to have delayed growth and development. At this age, children are particularly vulnerable to growth retardation, macro and micronutrient deficiencies, and common childhood illnesses such as malnutrition, diarrhoea, pneumonia and acute respiratory infections. All the malnourished children were found to have marasmus and none of them had kwashiorkor in the study subjects.

The study findings clearly indicate that a planned intervention was effective in increasing the nutritional status of preschool children in the prevention of protein energy malnutrition. Active intervention in the form of protein mix supplementation is very important in every malnourished child during the preschool period, as it helps in reduction of mortality and morbidity of dreadful diseases.

\section{REFERENCES}

[1] Wong. Wong's essentials of paediatric nursing. $6^{\text {th }}$ edn. New Delhi: Harcourt (India) Pvt. Ltd., 2001: p. 396.

[2] Community health care. [online] 9 Oct 2012 [cited 14 Oct 2012] URL: http://www.e health care.com.

[3] World Health Organization [online]. 1 Sep 2012 [cited 12 Sep 2012]: URL: http://www.whoindia.org.

[4] Alleviating protein energy malnutrition. www.google.com

[5] Malnutrition a matter of shame: PM. Deccan Herald. Newspaper: 2012;11(16):1.

[6] Sahu SK, Kumar SG, Bhat BV, et al. Malnutrition among under-five children in India and strategies for control. J Nat Sci Biol Med 2015;6(1):18-23.

[7] District Level Household and Survey (DLHS) - 4 Karnataka. http:// www.mohfw.nic.in

[8] IGNOU study material. Primary health nursing. New Delhi: Dek Key Printers 1994. 
[9] Rivera JA, Habicht JP. Effect of supplementary feeding on the prevention of mild-to-moderate wasting in conditions of endemic malnutrition in Guatemala. Bull World Health Organ 2002;80(12):926-32.

[10] Zavoshy R, Noroozi M, Jahanihashemi $H$, et al. Nutritional Intervention on malnutrition in 3-6 years old rural children in Qazvin Province, Iran. Pakistan Journal of Biological Sciences 2012;15(7):347-52.
[11] Parveen. A study to evaluate the effectiveness of Hyderabad mix on under five children of selected PHC area, Bangalore. 2013.

[12] Basit A, Nair S, Chakraborthy K, et al. Risk factors for under-nutrition among children aged one to five years in Udupi taluk of Karnataka, India. A case control study. Australas Med J 2012;5(3):163-7.

[13] Sharma SK. Nursing research and statistics. $1^{\text {st }}$ edn. Haryana: Reed Elsevier India Private Limited., 2011. 